\title{
Characterisation and biofilm screening of the predominant bacteria isolated from whey protein concentrate 80
}

\author{
Siti Norbaizura Md Zain ${ }^{1,2}$ • Steve H. Flint ${ }^{1}$ • \\ Rod Bennett ${ }^{1} \cdot$ Hong-Soon Tay $^{3}$
}

Received: 18 August 2015 / Revised: 7 October 2015 / Accepted: 8 October 2015 /

Published online: 3 November 2015

(C) INRA and Springer-Verlag France 2015

\begin{abstract}
The source of microbiological contamination of whey protein concentrate (WPC), a quality problem for the dairy industry, has not been thoroughly investigated. The objectives of this study were to identify the bacteria isolated from whey protein concentrate containing $80 \%$ protein (WPC 80 ) and determine their ability to form biofilms as a potential source of contamination in a whey processing line. Six Bacillus species including (percentage of isolates in brackets) Bacillus licheniformis (67\%), Bacillus cereus (19\%), Bacillus thuringensis (4\%), Bacillus subtilis (4\%), Bacillus pumilus (4\%) and Paenibacillus glucanolyticus (2\%) were identified based on BLAST databases in six different WPC80 batches. B. licheniformis was the predominant isolate. $B$. licheniformis are thermo-tolerant bacteria with the ability to form biofilm. This biofilm is a potential source of microbial contamination of product, resulting in microbial specification limits being exceeded. Spoilage of product may result from the metabolic products, such as enzymes, produced by these biofilms.
\end{abstract}

Keywords Bacillus licheniformis $\cdot$ Bacillus cereus $\cdot$ Paenibacillus glucanolyticus • Whey protein concentrate

\section{Introduction}

Whey is the liquid remaining after the production of cheese or the removal of fat and casein ( $80 \%$ of the proteins) from milk and contains predominantly Gram-positive

Steve H. Flint

S.H.Flint@massey.ac.nz

Hong-Soon Tay

Ryan.Tay@SingaporeTech.edu.sg

1 School of Food and Nutrition, Massey University, Palmerston NorthPrivate Bag 4442, New Zealand

2 Universiti Teknologi MARA Negeri Sembilan, Jalan Kuala Pilah, 72000 Kuala Pilah, Negeri Sembilan, Malaysia

3 Academic Programmes, Singapore Institute of Technology, 10 Dover Drive, Singapore 138683, Singapore, Singapore 
organisms from the starter population used in cheese and casein manufacture (lactic acid bacteria) or thermo-resistant species such as spore-forming Bacillus species (Schreiber 2001). Some starter bacteria, such as Streptococcus thermophilus and thermo-resistant Bacillus species can tolerate heat treatment such as thermalisation, pasteurisation and evaporation used in the manufacture of whey protein concentrate (WPC). These bacteria are therefore likely to form biofilm on manufacturing plant surfaces where they can grow and then be released into the whey being processed. Whey contains about $50 \%$ of the nutrients present in milk, comprising milk sugar (lactose), serum proteins (whey proteins), minerals, a small amount of fat and most of the water soluble minor nutrients from milk such as vitamins (Smithers 2008; Zadow 1992). This whey is concentrated by ultrafiltration and evaporation and then spray dried to provide a product that can be used as an ingredient in many foods.

Whey, formerly a waste product, became interesting to the food processing industries due to its physical and chemical properties, especially its protein, and nutritional qualities. The major whey product is WPC (Zadow 1992). It can be defined as the product derived from milk whey containing 50, 65 or $80 \%$ native proteins (Luck et al. 2013) and called WPC 50, WPC 65 and WPC 80, respectively. The individual protein composition in ultrafiltered WPC is about 68\% $\beta$-lactoglobulin, $21 \% \alpha$-lactalbumin and $10 \%$ serum proteins. This is approximately the same as present in whole milk (Delaney 1976). The amino acid composition of WPC and skim milk were compared, and the results showed WPC contains higher tryptophan and cysteine. This is due to the activity of starter bacteria in the manufacture of cheese whey (Macgibbon 2014). A schematic diagram of the WPC manufacturing process at one dairy plant in New Zealand is presented in Fig. 1.

The microflora in WPC varies depending on the type of whey with sweet whey showing a higher prevalence of thermophilic and mesophilic sporeformers compared with acid whey (Watterson et al. 2014). Aerobic sporeformers of particular concern in dairy products include the psychrotolerant Paenibacillus spp., mesophilic Bacillus spp.; for example, Bacillus licheniformis, Bacillus subtilis and Bacillus pumilus and thermophilic Anoxybacillus flavithermus and Geobacillus species in a group that is not well defined (Burgess et al. 2009, 2010; Watterson et al. 2014). Biofilm formation by some

Soluble Whey Protein Concentrate Production

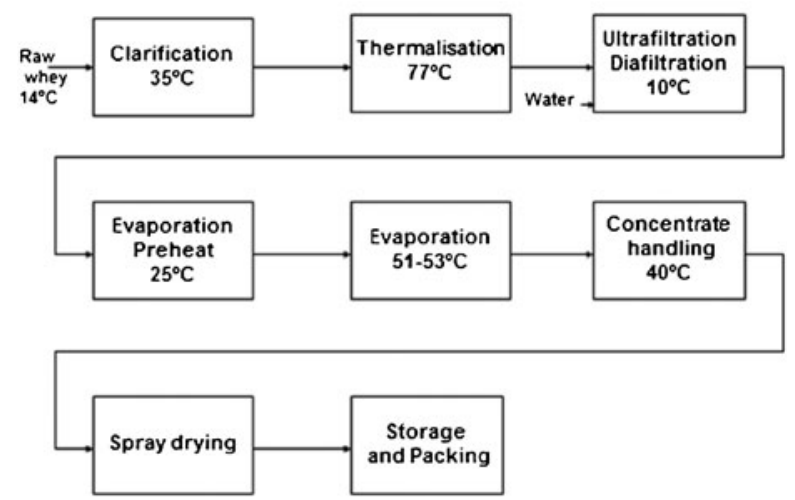

Fig. 1 A generic whey protein concentrate manufacturing process highlighting temperatures throughout the process that will influence microbial growth 
of these bacteria from the dairy industry, in particular the A. flavithermus and Geobacillus spp. in milk powder, has been reported and is believed to be the main cause of product contamination and possibly enzymes that lead to product spoilage (Scott et al. 2007). Sporeformers found in the dairy industry are the resistant forms of Bacillus and Clostridium species that withstand heat and chemical treatment that is used to control most bacteria in dairy manufacture. Generally, the microbial contaminants in products such as WPC are recorded as either thermophilic or mesophilic bacteria in routine testing. Dairy manufacturers have specifications for these groups of bacteria, but there is no requirement for further testing to identify the bacteria comprising these groups. The identification and characterisation of these bacteria could help in determining the effect on product quality and the risk of the manufacture of unacceptable product and the risk of product spoilage. This study aimed to identify the contaminants in six WPC 80 samples.

\section{Materials and methods}

\subsection{Source of samples}

Six WPC 80 samples from different manufacturing runs were obtained from one dairy manufacturing site in New Zealand. The samples in powdered form were received in 100 -g foil-lined paper pouches used to store samples from the manufacturing process for testing. The WPC 80 samples are listed in Table 1. Six different WPC 80 samples provided due to reported high bacterial counts were analysed to obtain the total microbial load using the aerobic plate count technique (see below) as used in the dairy industry to monitor the quality of the product.

\subsection{Isolation of bacteria}

Ten grams of each WPC 80 sample were diluted in $90 \mathrm{~g}$ of sterile $1 \%$ peptone water $(\mathrm{pH} 7.0)$ and homogenised using a peristaltic blender for 1 min prior to serial tenfold dilution to $1 \times 10^{-6}$ in $1 \%$ peptone. The pour plate technique was performed using milk plate count agar (MPCA) (Merck, BDH, Palmerston North, New Zealand) in duplicate

Table 1 Microbial load determined by plate counting on MPCA from WPC 80 samples incubated at $30{ }^{\circ} \mathrm{C}$ for $24 \mathrm{~h}$

\begin{tabular}{lll}
\hline Sample & Mesophilic aerobic plate count $\left(\mathrm{CFU} . \mathrm{g}^{-1}\right)$ & Thermophilic aerobic plate count $\left(\mathrm{CFU} . \mathrm{g}^{-1}\right)^{\mathrm{a}}$ \\
\hline A & $5.5 \times 10^{4}$ & $<10^{2}$ \\
B & $5.9 \times 10^{5}$ & $<10^{3}$ \\
C & $1.0 \times 10^{4}$ & $<10^{3}$ \\
D & $7.3 \times 10^{4}$ & $<10^{3}$ \\
E & $1.2 \times 10^{5}$ & $<10^{2}$ \\
F & $3.3 \times 10^{4}$ & $<10^{3}$ \\
\hline
\end{tabular}

${ }^{\text {a }}$ Spreading colonies for the thermophilic aerobic plate count meant no accurate counts could be obtained for this test 
to obtain numbers in the range of 30-300 colonies per plate. The agar plates were incubated aerobically at $30^{\circ} \mathrm{C}$ for $24 \mathrm{~h}$ for mesophilic bacteria and at $55^{\circ} \mathrm{C}$ for $18 \mathrm{~h}$ following an agar overlay to prevent spreading of thermophilic bacteria. Two to three single isolated colonies of different colony morphology were taken from the plates of each WPC 80 sample and restreaked onto MPCA to obtain pure cultures. Pure strains were stored at $-80{ }^{\circ} \mathrm{C}$ on beads (Microbank, Pro-Lab Canada).

\subsection{Phenotypic characterisation of isolates}

The pure cultures grown on MPCA were screened using microscopic observation of Gram-stained cells. The motility tests were done by the hanging drop technique and observed under light microscopy. These were used as additional confirmatory tests for some of the isolates, selected on the basis of colony morphology as presumptive B. licheniformis. Each culture was inoculated into Trypticase Soy Broth (TSB) and incubated 30,37 and $55{ }^{\circ} \mathrm{C}$ to observe growth at different temperatures based on optical density.

\subsection{Identification by PCR}

Gram positive bacilli with colonies indicative of $B$. licheniformis were further tested using species specific PCR targeting the gyrase $B$ gene using one set of species specific primers Blich-F1 5'-AKACGGAAGTGACGGGAAC-3' and Blich-R1 5'AGAAACTTTTCRAGCGCTT-3'(Huang et al. 2012). PCR amplification involved $20 \mu \mathrm{L}$ Master mix (5 Prime MasterMix-100 Rxns GmbH, Germany) consisting of dNTPs, magnesium chloride and Taq DNA polymerase, $24 \mu \mathrm{L}$ UltraPure $^{\mathrm{TM}}$ DNase/ RNase-Free Distilled Water (Invitrogen), $1 \mu \mathrm{L}$ forward primer, $1 \mu \mathrm{L}$ reverse primer and $4 \mu \mathrm{L}$ DNA template (unknown culture) to achieve a final volume of $50 \mu \mathrm{L}$. Amplification conditions were as follows; denaturing step at $94{ }^{\circ} \mathrm{C}$ for 7 min followed by 35 cycles with denaturation $\left(49^{\circ} \mathrm{C}\right.$ for $\left.60 \mathrm{~s}\right)$, annealing $\left(55^{\circ} \mathrm{C}\right.$ for $\left.60 \mathrm{~s}\right)$ and extension $\left(72{ }^{\circ} \mathrm{C}\right.$ for $\left.60 \mathrm{~s}\right)$ followed by a final extension at $72{ }^{\circ} \mathrm{C}$ for $15 \mathrm{~min}$. All PCR assays were carried out on the Techno thermal cycler (TC-400, Total Lab Systems, Auckland, New Zealand). The PCR products were visualised (E-Gel iBASE ${ }^{\mathrm{TM}}$, Invitrogen) using premade $2 \%$ agarose electrophoresis gel (E-Gel ${ }^{\circledR}$ EX with SYBR Glod II) and then visualised under UV Transilluminator, UVP, Inc (Chromator-Vue, San Gabriel, Californis, USA) and UVITEC (Cambridge, UK).

\subsection{Partial 16S rDNA gene sequencing}

For the colonies that were not indicative of $B$. licheniformis and for those isolates that did not produce a positive result with the species specific primers for the gyrase $\mathrm{B}$ gene of $B$. licheniformis, universal primers Bac27F 5'-AGAGTTTGATCCTGGCTCAG-3' and U1492R 5'-TACGGCTACCTTGTTACGACTT-3' were used to amplify a $1000 \mathrm{bp}$ part of the $16 \mathrm{~S}$ ribosomal deoxyribonucleic acid (rDNA) genome for sequencing, using the conditions in Flint et al. (1999b). Prior to sequencing, the PCR products were purified using a Zymo DNA Clean \& Concentrator ${ }^{\mathrm{TM}}-5$, USA kit and sent to UV/VIS spectrophotometry to check the DNA concentration $(1-2 \mu \mathrm{L})$ using the NanoDrop 1000 Spectrophotometer (Thermo Scientific, USA). Sequencing was done at the 
Massey University Sequencing Unit using the BigDye terminator v3.1 cycle sequencing kit and the results were analysed using the BLAST GeneBank.

\subsection{Biofilm screening}

A microtitre plate assay (Oh et al. 2007) was used to determine the ability of isolates to attach (adhere to a surface) and grow (reproduce on a surface) and form biofilm. A sterile 96-well flat-bottomed polystyrene microplate (Falcon ${ }^{\circledR}$ 96, 35 3072, Becton, Dickinson \& Company, USA) was filled with $230 \mu \mathrm{L}$ of TSB. Three wells were filled with TSB only as negative controls. Overnight culture $(20 \mu \mathrm{L})$ was added into the test wells, three wells per culture, and the plates were incubated aerobically for $24 \mathrm{~h}$ at 30,37 and $55^{\circ} \mathrm{C}$. The contents of the plates were removed by inverting the plates, and then, the wells were washed three times with $300 \mu \mathrm{L}$ of sterile distilled water. The remaining attached cells were fixed with $250 \mu \mathrm{L}$ of methanol per well for $15 \mathrm{~min}$. The liquid was discarded and the plates air-dried. The microplate wells were stained with $250 \mu \mathrm{L}$ of $0.05 \%(w / v)$ crystal violet for $5 \mathrm{~min}$. The excess stain was rinsed off by placing the microplate under running distilled water. After the microplates were air-dried, the dye bound to the adherent cells was resolubilized with $250 \mu \mathrm{L}$ of $33 \%(v / v)$ glacial acetic acid per well. The optical density (O.D.) of each well was measured at $570 \mathrm{~nm}$ using an automatic 96well microplate reader (BMG Labtech Spectrostar microplate reader, Bio-Tek Instruments, INC, Winooski, VT, USA). The biofilm formation of each $B$. licheniformis isolate (the predominant isolate) was tested using the microtitre plate assay with the strength of biofilm formation using the following range of O.D. values based on Oh et al. (2007). The cut-off O.D. (O.Dc) was defined as three SDs above the mean O.D. of the negative control. Strains were classified as follows: O.D. $<$ O.Dc $=$ no biofilm former, O.Dc $<$ O.D. $<(2 \times$ O.Dc $)=$ moderate biofilm former and O.D. $>(2 \times$ O.Dc $)=$ strong biofilm former. Differences in the degree of biofilm formation were examined by the Friedman test, followed by the Wilcoxon signed-rank test. $P$ values of $<0.05$ were considered significant. The O.Dc was determined as 0.5 for this study. The tests were done in triplicate at three different temperatures $(30,37$ and $55{ }^{\circ} \mathrm{C}$ ) to explore the influence of temperature on biofilm formation as the temperatures vary in different parts of the manufacturing process.

\section{Results and discussion}

\subsection{Total aerobic plate count}

The predominant bacteria in the WPC 80 samples were mesophilic bacteria (Table 2) with total mesophilic bacterial counts close to or exceeding the specification limits. The Australia New Zealand Food Safety Authority guideline for the mesophilic plate count for dried milk including whey powder is $5 \times 10^{4}$ CFU.g ${ }^{-1}$ (acceptable level) and $2 \times$ $10^{5} \mathrm{CFU}^{-1}$ (maximum). The thermophilic bacterial counts were all $<10^{3} \mathrm{CFU}^{-1} \mathrm{~g}^{-1}$ There is no guideline for thermophilic plate count. 
Table 2 Bacteria species identified using species specific PCR for B. licheniformis and 16S rDNA sequencing from six WPC 80 samples

\begin{tabular}{ll}
\hline Bacteria species & Number of positive isolates \\
\hline Bacillus licheniformis & 33 \\
Bacillus cereus/Bacillus thuringensis & 11 \\
Bacillus subtilis & 2 \\
Bacillus pumilus & 2 \\
Paenibacillus glucanolyticus & 1 \\
Total & 49 \\
\hline
\end{tabular}

\subsection{Isolation of bacteria}

The colony formations typical of B. licheniformis on MPCA were large opaque, adherent with irregular edges. These isolates were retrieved from MPCA and incubated at the appropriate temperature $\left(30^{\circ} \mathrm{C}\right)$. Although some of the isolates were observed to be facultative anaerobes, their growth in strict anaerobic conditions was not tested. Most of the facultative anaerobic and spore-forming bacteria produced pellicles after incubation at 30,37 and $55^{\circ} \mathrm{C}$ in TSB medium. Cells in pellicles are held together by an extracellular matrix consisting of exopolysaccharide and amyloid-like fibres largely composed of protein (Colodkin-Gal et al. 2012). This air-liquid interface might indicate that these bacteria could produce exopolysaccharide that generate biofilm formation.

Although the isolates were recovered at $30{ }^{\circ} \mathrm{C}$ (mesophiles), some grew at $55{ }^{\circ} \mathrm{C}$ (thermophilic). These results are similar to those of Lücking et al. (2013). Watterson et al. (2014) reported that sweet whey and non-fat dry milk showed higher prevalence of thermophilic and mesophilic sporeformers compared with acid whey and WPC 80. Some of the bacteria isolated in the present trial could grow at both 30 and $55{ }^{\circ} \mathrm{C}$. Facultative thermophiles in dairy processing belong to the Bacillus genus and include species such as Bacillus coagulans, B. licheniformis and B. pumilus that are able to grow at both mesophilic and thermophilic temperatures (Burgess et al. 2013; Flint et al. 2011a, b).

The isolates obtained from the six WPC 80 samples were predominantly Bacillus species with rod-shaped purple-violet colour on Gram staining, as expected from colony morphology. All of the isolated bacteria were Gram positive, mostly sporeformers and motile based on microscopic observation.

\subsection{PCR identification and 16S rDNA sequencing}

The identification of suspect $B$. licheniformis isolates based on colony morphology was confirmed as expected using species specific PCR. B. licheniformis was the predominant isolate making up 33 of the 49 isolates (Table 2).

These aerobic-spore-forming bacteria are frequent contaminants isolated from milk or dairy processing environments (Alvarez-Ordóñez et al. 2014; Aouadhi et al. 2013; Brown 2000; Buehner et al. 2014; Burgess et al. 2013; Flint et al. 2001; Frank 1997; Lücking et al. 2013; Masiello et al. 2014) predominantly in milk powder (Reginensi et al. 2001; Scott et al. 2007; Yuan et al. 2012) but not commonly reported in whey 
powder. The origin of $B$. licheniformis is believed to be from soil and the heat resistant spores survive pasteurisation of milk and the cheese manufacturing process, thus potentially contaminating the whey. Buehner et al. (2014) reported that $B$. licheniformis was the major contaminant in milk regardless of the seasons (winter or summer). B. licheniformis can contribute to product spoilage through the production of enzymes (Teh et al. 2012). The second most isolated Bacillus species were Bacillus cereus/B. thuringensis with 11 isolates. B. cereus is capable of producing emetic and diarrhoeal toxin that can cause food poisoning (Burgess et al. 2010; De Jonghe et al. 2010). The next most isolated species were B. subtilis and B. pumilus. These three Bacillus species are also common contaminants in dairy products (Frank 1997; Masiello et al. 2014). Certain mesophilic Bacillus spp. (e.g. B. subtilis, B. pumilus and $B$. licheniformis) can also grow at temperatures that are used to detect and enumerate thermophilic organisms (i.e., $55^{\circ} \mathrm{C}$ ). In one recent trial, WPC 80 contained thermophilic spore counts detected by direct plating (Watterson et al. 2014).

The present study identified one isolate as Paenibacillus glucanolyticus (Table 2). This is the first time that this bacterium has been isolated from WPC 80, and no records can be found of this bacterium being isolated in New Zealand. It was identified using 16S rDNA gene sequencing with confidence level 99\% (BLAST) and 94\% (Seqmatch). The P. glucanolyticus isolate was observed using scanning electron microscope (SEM) and the intercellular properties of the cells together with the spores were observed using transmission electron microscope (TEM). The cells were long $>3.0 \mu \mathrm{m}$ and thin $<0.9 \mu \mathrm{m}$ and produced oval terminal spores that markedly distended the sporangium. Interestingly, their spores portrayed a very unique shape, different from spores of Bacillus species.

This bacterium, formerly included in the genus Bacillus, is a facultative anaerobic, long, thin rod-shaped bacterium with terminal spore formation and may be isolated from various soils. Normal environments of Paenibacillus strains include soil, the rhizosphere of plants, water, diseased insect larvae and food products (Daane et al. 2002; Lorentz et al. 2006). Recently, Ferrand et al. (2013) published a case report on P. glucanolyticus infection in a 65-year-old patient with type 2 diabetes who developed a cardiac device-related endocarditis. This is believed to be the first ever report associating $P$. glucanolyticus with human infection.

\subsection{Biofilm formation screening by $B$. licheniformis isolates}

There is a lack of information on the biofilm-forming ability of $B$. licheniformis and the importance of biofilms of this bacterium in the contamination of dairy products.

Three B. licheniformis isolates (C55C01, E30C11 and $\mathrm{F} 55 \mathrm{C} 12)$ produced strong biofilm O.D. $570 \mathrm{~nm} \geq 0.5$ at $30{ }^{\circ} \mathrm{C}$ with an O.D. at 3.5 (the highest absorbance from microtitre plate reader) (Table 3, Fig. 2). Nine B. licheniformis isolates produced strong biofilms at $37{ }^{\circ} \mathrm{C}$ suggesting $37{ }^{\circ} \mathrm{C}$ is the optimum temperature for $B$. licheniformis to form biofilm. $B$. licheniformis is known as a thermo-tolerant bacterium and able to grow at temperatures up to $55^{\circ} \mathrm{C}$ (Dhakal et al. 2013; Smithers 2008). However, in this study, most of the $B$. licheniformis isolated from six different whey samples did not produce biofilm at $55^{\circ} \mathrm{C}$. Biofilm formation at $55^{\circ} \mathrm{C}$ was generally poor with only three isolates showing a tendency to form biofilm at this temperature. Moderate biofilm formation in TSB at $37{ }^{\circ} \mathrm{C}$ was produced by three B. licheniformis isolates. The majority of 
Table 3 Biofilm strength of $B$. licheniformis measured using the microtitre plate assay in trypticase soy broth at three different temperatures (strength determined by the method of Oh et al. (2007))

\begin{tabular}{llll}
\hline & \multicolumn{2}{l}{ Biofilm formation (number of isolates in each category) } \\
\cline { 2 - 4 } Temperature $\left({ }^{\circ} \mathrm{C}\right)$ & No biofilm & Moderate biofilm & Strong biofilm \\
\hline 30 & 30 & 0 & 3 \\
37 & 21 & 3 & 9 \\
55 & 30 & 2 & 1 \\
\hline
\end{tabular}

B. licheniformis strains were unable to produce biofilm at any of the three temperatures $\left(30,37\right.$ and $\left.55^{\circ} \mathrm{C}\right)$ in the TSB medium. However, they may produce biofilm under the conditions of a dairy manufacturing plant on a protein-fouled surface.

\subsection{General discussion}

Microbial contamination of dairy products is controlled by heat treatment such as pasteurisation to kill pathogens and prevent spoilage. However, some thermophilic and mesophilic organisms as well as spore-forming bacteria can survive and contribute to the spoilage of the milk. These bacteria include S. thermophilus and spore-forming bacteria Anoxybacillus, Geobacillus and Bacillus species which can survive subsequent dairy manufacturing processes and contaminate whey (Flint et al. 1997, 1999a, b, 2000). Parkar et al. (2003) showed a variety of thermophilic bacilli strains including Geobacillus, Anoxybacillus, B. licheniformis, B. coagulans and B. pumilus were able to attach to both stainless steel and milk foulant in similar numbers. Dairy product contamination is believed to be enhanced by the growth of biofilms in the manufacturing plant. Biofilms may develop on any surface where the conditions are suitable for bacterial growth (Costerton 1995; Donlan 2002; Flint et al. 2001). The contribution of biofilms of these thermo-resistant bacteria to the contamination of whey products is unknown.

Product quality can be affected by these sporeformers in three different ways: by production of toxin or spoilage enzymes or by interfering in downstream processing steps (De Jonghe et al. 2010; Pasvolsky et al. 2014). Enzymes like protease and lipase do influence the quality of milk and milk products by altering the sensory qualities such as texture, taste, aroma and nutritional value (Chen et al. 2003; Teh et al. 2012, 2013). Bacillus and Paenibacillus produce a variety of proteases, lipases and phospholipases that impact the texture of dairy product and cause off-flavours (Lücking et al. 2013). The effect of the bacteria isolated in the present trial on the sensory quality of WPC 80 is unknown.

The ability of $B$. licheniformis to form biofilm has been demonstrated, and this is important as this is the most likely source of contamination of high numbers of B. licheniformis and their enzymes in product. Locating the zone in the manufacturing plant where these biofilms grow will be important for their control. We know that B. licheniformis cannot grow at $10{ }^{\circ} \mathrm{C}$, the temperature used in the ultrafiltration plant; therefore, this cannot be a site of biofilm development for these bacteria. Other parts of the WPC manufacturing plant where conditions are likely to be appropriate for 


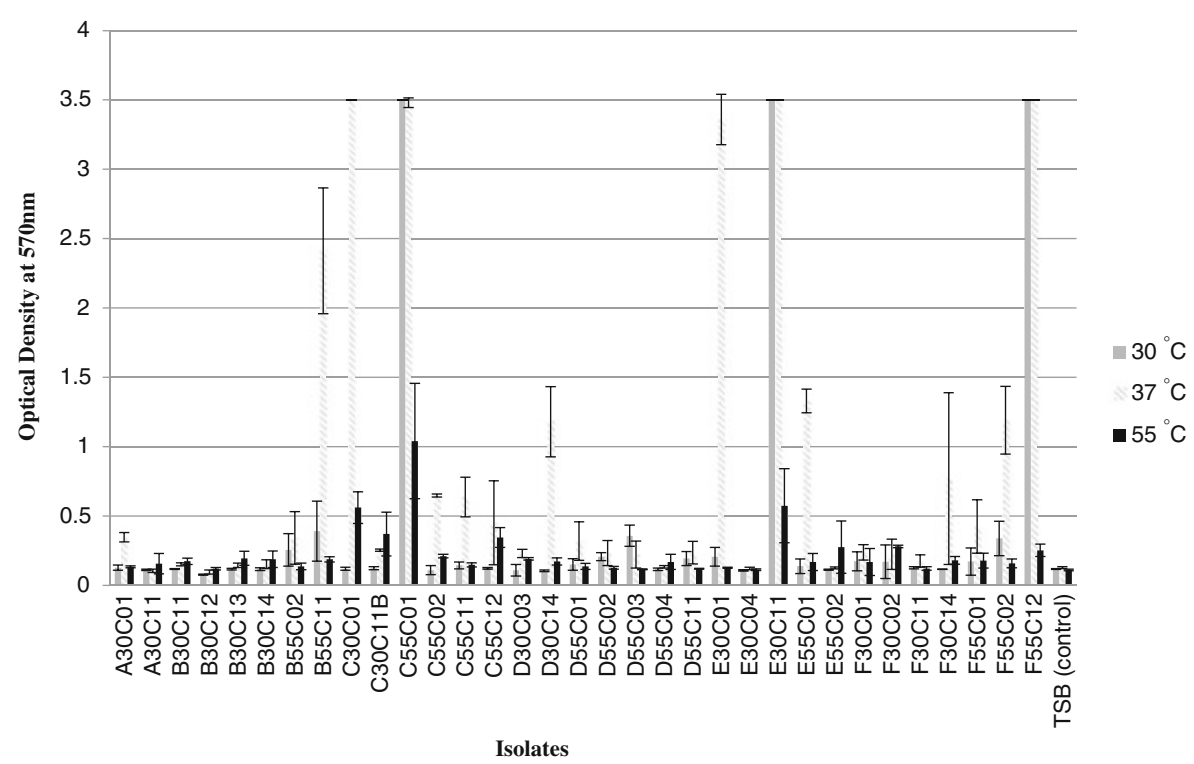

Fig. 2 The O.D. scores of the dairy isolate biofilms at 570-nm absorbance using the microtitre plate assay at three different temperatures. The results represent the amount of crystal violet stain retained on the test plate indicating the presence of biofilm

B. licheniformis biofilm development are during clarification and evaporation, and this needs to be confirmed.

\section{Conclusion}

Mesophilic bacteria, in particular, B. licheniformis may predominate in WPC 80, contributing to aerobic plate counts close to or exceeding specification limits. These bacteria may produce biofilm under laboratory conditions with $37{ }^{\circ} \mathrm{C}$ being the favoured temperature compared with 30 and $55^{\circ} \mathrm{C}$. This may be a source of product contamination during the manufacture of WPC 80. The control of $B$. licheniformis during the manufacture of WPC 80 is important to maintain product quality.

\section{References}

Alvarez-Ordóñez A, Begley M, Clifford T, Deasy T, Considine K, O’Connor P, Ross RP, Hill C (2014) Investigation of the antimicrobial' activity of Bacillus licheniformis strains isolated from retail powdered infant milk formulae. Probiotics Antimicrob Proteins 6:32-40

Aouadhi C, Maaroufi A, Mejri S (2013) Incidence and characterisation of aerobic spore-forming bacteria originating from dairy milk in Tunisia. Int J Dairy Technol 67:95-102

Brown KL (2000) Control of bacterial spores. Br Med Bull 56:158-171

Buehner KP, Anand S, Garcia A (2014) Prevalence of thermoduric bacteria and spores on 10 Midwest dairy farms. J Dairy Sci 97:1-8

Burgess SA, Brooks JD, Rakonjac J, Walker KM, Flint SH (2009) The formation of spores in biofilms of Anoxybacillus flavithermus. J Appl Microbiol 107:1012-1018 
Burgess SA, Lindsay D, Flint SH (2010) Thermophilic bacilli and their importance in dairy processing. Int J Food Microbiol 14:215-225

Burgess SA, Flint SH, Lindsay D (2013) Characterization of thermophilic bacilli from a milk powder processing plant. J Appl Microbiol 116:350-359

Chen L, Daniel RM, Coolbear T (2003) Detection and impact of protease and lipase activities in milk and milk powders. Int Dairy J 13:255-275

Costerton JW (1995) Overview of microbial biofilms. J Ind Microbiol 15:137-140

Daane LL, Harjono I, Barns SM, Launen LA, Palleroni NJ, Haggblom MM (2002) PAH-degradation by Paenibacillus spp. and description of Paenibacillus naphthalenovorans sp. nov., a naphthalene-degrading bacterium from the rhizosphere of salt marsh plants. Int J Syst Evol Microbiol 52:131-139

De Jonghe V, Cooreevits A, De Block J, Van Coillie E, Grijspeerdt K, Herman L, de Vos P, Heyndrickx M (2010) Toxinogenic and spoilage potential of aerobic spore-formers isolated from raw milk. Int J Food Microbiol 136:318-325

Delaney RAM (1976) Composition, properties and uses of whey protein concentrate. J Soc Dairy Technol 29: 91-101

Dhakal R, Chauhan K, Seale BR, Deeth HC, Pillidge CJ, Powell IB, Craven H, Turner MS (2013) Genotyping of dairy Bacillus licheniformis isolates by high resolution melt analysis of multiple variable number tandem repeat loci. Food Microbiol 34:344-351

Donlan RM (2002) Biofilms: microbial life on surfaces. Emerg Infect Dis 8:881-890

Ferrand J, Hadou T, Selton-Suty C, Goehringer F, Sadoul N, Alauzet C, Lozniewski A (2013) Cardiac devicerelated endocarditis caused by Paenibacillus glucanolyticus. J Clin Microbiol 51:3439-3442

Flint SH, Brooks JD, Bremer PJ (1997) The influence of cell surface properties of thermophilic streptococci on attachment to stainless steel. J Appl Microbiol 83:508-517

Flint SH, van den Elzen H, Brooks JD, Bremer PJ (1999a) Removal and inactivation of thermo-resistant streptococci colonising stainless steel. Int Dairy J 9:429-436

Flint SH, Ward LJH, Brooks JD (1999b) Streptococcus waius sp. nov., a thermophilic streptococcus from a biofilm. Int J Syst Bacteriol 49:759-767

Flint SH, Brooks JD, Bremer PJ (2000) Properties of the stainless steel substrate influencing the adhesion of thermo-resistant streptococci. J Food Eng 43:235-242

Flint SH, Palmer J, Bloemen K, Brooks J, Crowford R (2001) The growth of Bacillus steathermophilus on stainless steel. J Appl Microbiol 90:151-157

Flint S, Palmer J, Bremer P, Seale B, Brooks J, Lindsay D, Burgess S (2011a) In: Biofilm formation. Encyclopaedia of dairy sciences, 2nd ed. Academic Press, San Diego

Flint SH, Tang X, Bennett RJ, Brooks JD (2011b) In: Controlling the microbiology of whey and whey products. Whey: types, composition and health implications. Nova publishers, New York

Frank JF (1997) Milk and dairy products. In: Doyle MP, Beuchat LR, Montville TJ (eds) Food microbiology: fundamentals and frontiers. American Society for Microbiology, Washington, D.C

Huang C-H, Chang M-T, Huang L, Chu W-S (2012) Development of a novel PCR assay based on the gyrase B gene for species identification of Bacillus licheniformis. Mol Cell Probes 26:215-217

Kolodkin-Gal I, Cao S, Chai L, Bottcher T, Kolter R, Clardy J, Losick RA (2012) Self-produced trigger for biofilm disassembly that targets exopolysaccharide. Cell 149:684-692

Lorentz RH, Ártico S, da Silveira AB, Einsfeld A, Corção G (2006) Evaluation of antimicrobial activity in Paenibacillus spp. strains isolated from natural environment. Lett Appl Microbiol 43:541-547

Luck PJ, Vardhanabhuti B, Yong YH, Laundon T, Barbano DM, Foegeding EA (2013) Comparison of functional properties of $34 \%$ and $80 \%$ whey protein and milk serum protein concentrates. J Dairy Sci 96 : $5522-5531$

Lücking G, Stoeckel M, Atamer Z, Hinrichs J, Ehling-Schulz M (2013) Characterization of aerobic sporeforming bacteria associated with industrial dairy processing environments and product spoilage. Int $\mathrm{J}$ Food Microbiol 166:270-279

Macgibbon J (2014) Whey to go. Ngaio Press, Martinborough

Masiello SN, Martin NH, Watters RD, Galton DM, Schukken YH, Wiedmann M, Boor KJ (2014) Identification of dairy farm management practices associated with the presence of psychrotolerant sporeformers in bulk tank milk. J Dairy Sci 97:4083-4096

Oh S-W, Chen P-C, Kang D-H (2007) Biofilm formation by Enterobacter sakazakii grown in artificial broth and infant milk formula on plastic surface. J Rapid Methods Autom Microbiol 15:311-319

Parkar SG, Flint SH, Brooks JD (2003) Physiology of biofilms of thermophilic bacilli-potential consequences for cleaning. J Ind Microbiol Biotechnol 30:553-560

Pasvolsky R, Zakin V, Ostrova L, Shemesh M (2014) Butyric acid released during milk lipolysis triggers biofilm formation of Bacillus species. Int J Food Microbiol 181:19-27 
Reginensi SM, Gonzàlez MJ, Olivera JA, Sosa M, Juliano P, Bermŭdez J (2001) RAPD-based screening for spore forming bacterial populations in Uruguayan commercial powdered milk. Int J Food Microbiol 148: $36-41$

Schreiber R (2001) Heat-induced modifications in casein dispersions affecting their rennetability. Int Dairy J 11:553-558

Scott SA, Brooks JD, Rakonjac J, Walker KMR, Flint S (2007) The formation of thermophilic spores during the manufacture of whole milk powder. Int J Dairy Technol 60:109-117

Smithers GW (2008) Whey and whey proteins - from 'gutter-to-gold'. Int Dairy J 18:695-704

Teh KH, Flint S, Palmer J, Andrewes P, Bremer P, Lindsay D (2012) Proteolysis produced within biofilms of bacterial isolates from raw milk tankers. Int J Food Microbiol 157:28-34

Teh KH, Lindsay D, Palmer J, Andrewes P, Bremer P, Flint S (2013) Lipolysis within single culture and coculture biofilms of dairy origin. Int J Food Microbiol 163:129-135

Watterson MJ, Kent DJ, Boor KJ, Wiedmann M, Martin NH (2014) Evaluation of dairy powder products implicates thermophilic sporeformers as the primary organisms of interest. J Dairy Sci 97:2487-2497

Yuan D-D, Liu G-C, Ren G-Y, Zhang D, Zhao L, Kan C-P, Zhang L-B (2012) A survey on occurrence of thermophilic bacilli in commercial milk powders in China. Food Control 2:752-757

Zadow JG (1992) Whey and lactose processing. Elsevier Science, England 